\title{
Distribution of resting cysts of the potentially toxic dinoflagellate Alexandrium pseudogonyaulax in recently-deposited sediment within Bizerte Lagoon (Mediterranean coast, Tunisia)
}

\author{
Habiba Zmerli Triki ${ }^{a}$,*, Ons Kéfi Daly-Yahia ${ }^{a}$, Dhafer Malouche ${ }^{\mathrm{b}}$, Yosr Komiha ${ }^{\mathrm{a}}$, Alan Deidun ${ }^{\mathrm{c}}$, \\ Mouldi Brahim ${ }^{\mathrm{d}}$, Mohamed laabir ${ }^{\mathrm{e}}$ \\ ${ }^{a}$ Tunisian National Agronomic Institute (INAT), IRESA - Carthage University, U.R Marine Biology (FST El Manar I), 43 Avenue Charles Nicolle, 1082 Tunis, Tunisia \\ ${ }^{\mathrm{b}}$ Ecole Supérieure de la Statistique et de l'Analyse de l'Information, Tunisia \\ ${ }^{\mathrm{c}}$ IOI - Malta Operational Centre, University of Malta, Msida, Malta \\ ${ }^{\mathrm{d}}$ Institut National des Sciences et Technologie de la Mer (INSTM), Tunisia

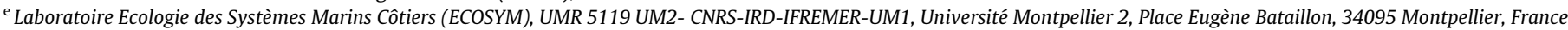

\section{A R T I C L E I N F O}

\section{Article history:}

Available online 27 May 2014

\section{Keywords:}

Alexandrium pseudogonyaulax

Harmful algae

Resting cysts

Mapping

Mediterranean Lagoon of Bizerte

Sediment characteristics

\begin{abstract}
A B S T R A C T
This study investigated the spatial distribution of Alexandrium pseudogonyaulax resting cysts in recentlydeposited sediment of Bizerte lagoon (South-Western Mediterranean, Tunisia). This lagoon is the subject of many anthropogenic impacts, such as holding important fishing and aquaculture activities. A. pseudogonyaulax has been shown to produce Goniodomin A, which is a biologically-active compound. We showed that this dinoflagellate produces two types of resting cysts, which could be distinguished by the presence or the absence of a paratabulate wall. The average cyst density across the whole lagoon was rather high, reaching 639 cysts $^{-1}$ of dry sediment (DS). Cyst densities varied widely among the sampled stations, with the highest density of 1685 cyst $\mathrm{g}^{-1}$ DS being recorded at station 51 near a mussel farm. With respect to sediment characteristics, the highest cyst densities were found within silty sediments with high water content values. The distribution of $A$. pseudongoyaulax cysts in Bizerte lagoon appears to be related to hydrodynamic factors.
\end{abstract}

(c) 2014 Elsevier Ltd. All rights reserved.

\section{Introduction}

Resting cysts play a crucial role in the population dynamics of dinoflagellate species and their geographical distribution (Steidinger and Garcès, 2006). These cysts enhance the survival capacity of such species under adverse environmental conditions, as well as the genetic structure of the populations through genetic recombination (Anderson and Wall, 1978; Genovesi-Giunti et al., 2006). Cyst seed beds provide germling cells for the inoculation of the water column, leading to the establishment of planktonic populations when the environmental conditions are suitable once again. Cysts can remain in the sediments for decades, thus providing a genetic repository (Belmonte et al., 1997) which can potentially lead to the emergence of harmful dinoflagellate cells that could form blooms once specific environmental factors optimum for their development arise.

\footnotetext{
* Corresponding author. Tel.: +216 52612929.

E-mail address: bibarouma@hotmail.fr (H.Z. Triki).
}

Little information is available on the distribution, seasonal variation and ecology of Alexandrium species in the southern Mediterranean waters (Daly Yahia-Kefi et al., 2001; Turki et al., 2007). Data is lacking on the distribution of dinoflagellate cysts in the benthic sediment of Mediterranean waters (Satta et al., 2010; Genovesi et al., 2013), with such data being completely absent for southern Mediterranean areas. In Tunisia, toxic blooms were responsible for heavy fish mortality in the Gulf of Gabès (South Tunisia) in 1995. Most of the toxicity episodes in Tunisian waters involving a breach of water quality standards for coastal waters in the last 6 years appear to be linked to Karenia selliformis, Alexandrium minutum, Coolia monotis and Karlodinium veneficum proliferations (Ben Naila et al., 2012). In November 2007, a bloom of Alexandrium catenella was recorded in Bizerte Lagoon, with observed cell concentrations of up to $20 \times 10^{4}$ cells $\mathrm{L}^{-1}$. For the first time, cultured mussels (Mytilus galloprovincialis) were contaminated with paralytic toxins as a result of this event, with toxin concentrations exceeding the set threshold ( $800 \mu \mathrm{g}$ Eq STX kg ${ }^{-1}$ of flesh) (Turki, 2004).

Our study was carried out in the Bizerte lagoon, located in the north of Tunisia and considered to be the most productive Tunisian 
lagoon, holding nine important oysters and mussels farms. The lagoon lies in the vicinity of several towns and industrial facilities. This ecosystem is affected by various anthropogenic activities, including domestic sewage and industrial waste discharge (Bejaoui et al., 2008). Our preliminary investigations revealed that A. pseudogonyaulax (Biecheler) Horiguchi ex Yuki et Fukuyo cysts showed the highest cyst abundances of all dinoflagellate species cysts within the benthic sediment of Bizerte lagoon. However, to date, no blooms of this dinoflagellate species have been recorded within Bizerte Lagoon. The high cyst densities of A. pseudogonyaulax encountered in the lagoon sediment and its potentially toxic character led us to take a special interest in this species. A. pseudogonyaulax (Biecheler) Horiguchi ex Yuki et Fukuyo, originally called Goniodoma pseudogonyaulax Biecheler, is a marine brackish neritic dinoflagellate (Faust and Gulledge, 2002). It was reported for the first time by Biecheler (1952) in the Thau lagoon (Mediterranean, France), then subsequently recorded in Italy (Montresor, 1995), Spain (Alfacs Bay) (Bravo et al., 2006), along the Tunisian coast (Daly Yahia-Kefi et al., 2001; Turki, 2004) and thereafter in many non-Mediterranean marine areas such as Fundy Bay (USA), the German Bight, the coastal waters of Japan and the Gulf of Georgia (British Columbia) (Klein et al., 2010). This dinoflagellate species has been reported as a bloom-forming species in the Norwegian Sea (Throndsen et al., 2007) and in Alfacs Bay (Ebro Delta) during the summer of 2003 and 2004 (Bravo et al., 2006). Blooms belonging to A. pseudogonyaulax normally have a high biomass and may be responsible for harmful effects witnessed within high marine trophic levels. This dinoflagellate has been shown to produce Goniodomin A, a dangerous neurotoxin that can result in harmful effects to vertebrate consumers through the paralytic shellfish poisoning (PSP) syndrome (Klein et al., 2010). This toxin has a wide range of biological activities, such as the inhibition of fungal growth and the termination of cell division in fertilized sea-urchin eggs (Murakami et al., 1988). Furthermore, A. pseudogonyaulax has been shown to be mixotrophic, with cells releasing toxic mucus which may aid in prey capture and uptake (Blossom et al., 2012). This behavior could favor the success of this species within the sampled habitat.

The objectives of the present study were (i) to describe, for the first time in southern Mediterranean waters (Bizerte lagoon, Tunisia), the vegetative cells and resistant cysts of the toxic dinoflagellate $A$. pseudogonyaulax on the basis of morphological criteria and (ii) to assess the densities of its resting cysts across Bizerte lagoon sediments. Several descriptors of sediment (granulometry, water content and organic matter) were determined in order to investigate whether resting cyst distribution could be correlated with sediment characteristics. The influence of hydrodynamic parameters on the same resting cyst distribution was also discussed.

\section{Materials and methods}

\subsection{Study area}

Bizerte Lagoon is located in northern Tunisia $\left(37^{\circ} 8^{\prime}-37^{\circ} 14^{\prime} \mathrm{N}\right.$, $9^{\circ} 46^{\prime}-9^{\circ} 56^{\prime} \mathrm{E}$ ) covering $128 \mathrm{~km}^{2}$ with a maximum width of $11 \mathrm{~km}$, a maximum length of $13 \mathrm{~km}$ and a water depth which ranges between 2 and $14 \mathrm{~m}$. This lagoon communicates with the Mediterranean Sea via the $6 \mathrm{~km}$-long Bizerte channel. In the west, it is connected to the lake Ichkeul through the $5 \mathrm{~km}$ long Tinja river (Fig. 1). Furthermore, Bizerte lagoon receives freshwater influx from eighteen different streams which discharge freshwater all over its surface.

In the Bizerte lagoon, water current circulation is mostly dictated by the predominating west-northwestern wind, which has an influence all throughout the year (Harzallah, 2003; Bejaoui and Harzallah, 2005; Bejaoui et al., 2008; Bejaoui 2009). Surface currents are strong at the northern, western and southern extremities of the lagoon, whereas they are relatively weak in the central part of the lagoon, which explains the accumulation of fine sediments in this part of the lagoon (Bejaoui, 2009). At the bottom of the lagoon, where the influence of the surface wind is suppressed, the direction of the water flow tilts to the north-west direction and passes through the central part of the lagoon. An important feature of the water circulation in the Bizerte lagoon is the presence of three circulation gyratory cells, sited in the northern, southern and western sections of the lagoon (Harzallah, 2003; Bejaoui et al., 2008; Bejaoui, 2009).

Sediment grain-size properties differ in different regions of the lagoon. The western lagoon stations, located in the deepest areas of the lagoon, are characterized by muddy sediments. The central zone, where sediment deposition is most active, is characterized by silt-mud sediment while the eastern lagoon zone is mainly muddy. Finally, the percentage of sand exceeds $75 \%$ within benthic sediment located along the coastal areas of the lagoon (Brahim et al., 2008).

\subsection{Sampling method}

The sampling campaign was carried out the 3th, 7th, 12th, 19th and 26th July and 7th August 2012, by SCUBA divers using cylindrical cores ( $26 \mathrm{~cm}$ long, $4 \mathrm{~cm}$ diameter). Fifty-five stations, with three replicates each, were adopted during the sampling campaign (Fig. 2) resulting in a total of 165 surface sediment samples being collected. According to Dale (1983), cysts often settle in the deeper, calmer parts of bays. This suggests that they should be more common in silt-rich sediments, which normally accumulate in these parts of the lagoon (Horner et al., 2011). The location of the chosen sampling stations was selected according to the following criteria: water current direction and sediment properties. Forty-three sampling stations were located in the central portions of the lagoon, at a distance of $0.7 \mathrm{~km}$ from each other. At these central sampling stations, fine sediment particle sizes were dominant since bottom water currents were weak. The other twelve sampling stations, spaced at $1.5 \mathrm{~km}$ intervals from each other, were located within benthic areas characterized by coarser sediment particle sizes and stronger bottom currents. The water immediately above the seabed, at the locations where sediment cores were collected, was sampled and filtered through a $20 \mu \mathrm{m}$ mesh. The upper $3 \mathrm{~cm}$ of three cores at the same station were sectioned and mixed, then stored in the dark at $4{ }^{\circ} \mathrm{C}$ until further analyses. In order to check for the presence of motile vegetative cells of Alexandrium sp. in the deep water layer and to assess the concentrations of dissolved nitrogen and phosphate compounds, $1 \mathrm{~L}$ of water was sampled for subsequent analyses. At the water-sediment interface, water temperature and salinity were measured by means mercuric thermometer and conductivity meters (cond 3110 SET 1), respectively.

\subsection{Sediments characteristics}

\subsubsection{Water $\left(\mathrm{H}_{2} \mathrm{O}\right)$ and organic matter $(\mathrm{OM})$ contents}

The determination of water content in the sediment sample reduces the variability in resting cyst (RCs) density values, since these are often correlated with the sediment water content. Consequently, the cyst densities are expressed as cyst number $\mathrm{g}^{-1}$ dry sediment (DS). The wet sediment (Ww) replicates were mixed and then dried for 7 days at $60{ }^{\circ} \mathrm{C}$. The resulting dry sediment was weighed $(\mathrm{Wd})$. The sediment water content was calculated using the following equation (Eq. (1)):

$\mathrm{H}_{2} \mathrm{O} \%=[(\mathrm{WW}-\mathrm{Wd}) * 100] / \mathrm{WW}$. 


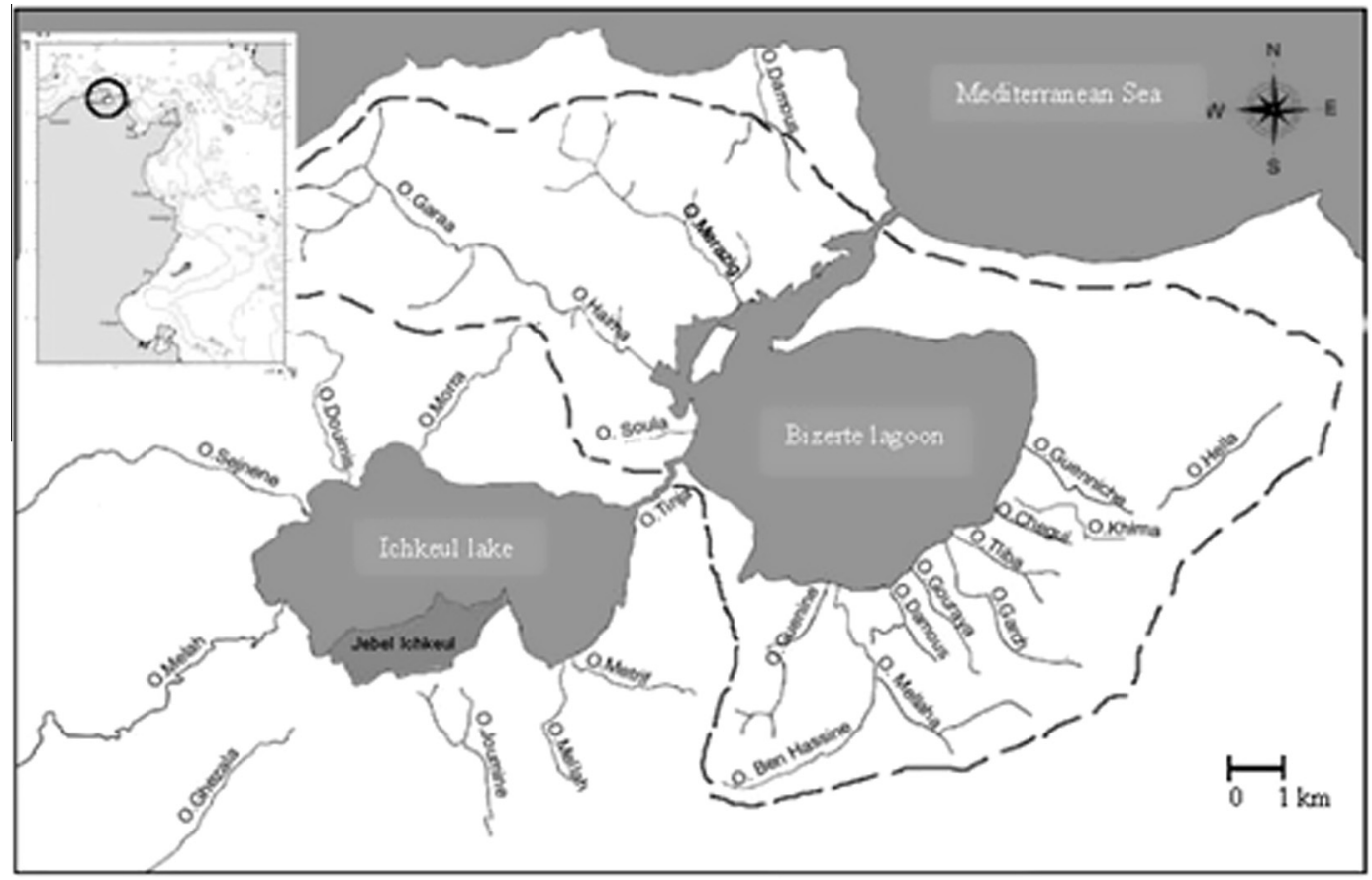

Fig. 1. Map of the Bizerte lagoon showing connections with Ichkeul lake and Mediterranean sea reproduced from Turki et al. (2007).

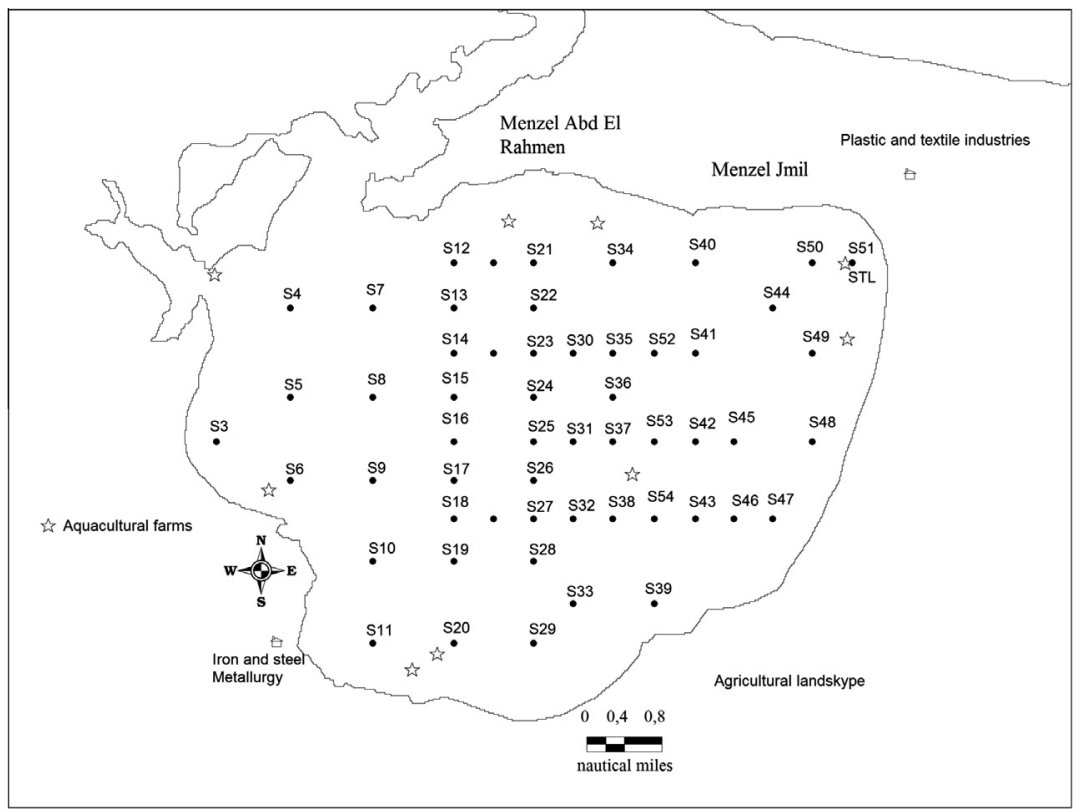

Fig. 2. Sediment sampling stations in the Bizerte lagoon.

The organic matter (OM) content was calculated through the loss on ignition protocol. The sediment was dried at $450{ }^{\circ} \mathrm{C}$ for $12 \mathrm{~h}$ so to evaporate organics in the form of carbon dioxide. The resulting dry sample was weighed, recording the new dry weigh $\left(\mathrm{Wd}_{1}\right)$. The percentage of $\mathrm{OM}$ was calculated using the following equation (Eq. (2)):

$\mathrm{OM} \%=\left[\left(\mathrm{Wd}-\mathrm{Wd}_{1}\right) * 100\right] / \mathrm{Wd}_{1}$

\subsubsection{Granulometry}

The mean particle size of the sediment was determined using the laser particle sizer Malver Master TM LSE. This device measures the percentage of the volume occupied by each size class by determining the "Obscuration" of a laser beam through a cell in which the sample has been injected as a suspension in water. The obtained data were processed using Mastersizer software, which estimates the particle grain-size parameters of the three replicates as well as the average cumulative curve.

\subsection{Resting cysts extraction and quantification}

Sediment samples were kept in the dark at $4{ }^{\circ} \mathrm{C}$ and processed within $24 \mathrm{~h}$ after collection. RCs extraction was done using the gradient density method, adding Polytungstate solution (PST) for the 
separation of mineral constituent. Duplicates for each sampling station were taken for RCs quantification. One gram of wet sediment was taken randomly and mixed with $50 \mathrm{ml}$ of $0.2 \mu \mathrm{m}$ Filtered Sea Water (FSW), subjected for 3 min to the Ultrasonic cleaner bath to separate cysts from mucus and sediment grains, and then sieved through 100 and $20 \mu \mathrm{m}$ mesh sizes. The sample retained by the $20 \mu \mathrm{m}$ mesh was collected with FSW and was than centrifuged (MIKRO 22R HETTICH centrifuges) at $3000 \mathrm{rev} / \mathrm{min}$ for $10 \mathrm{~min}$ at $4{ }^{\circ} \mathrm{C}$. The pellet obtained was refilled with PST, than centrifuged at the same conditions. The recovered supernatant containing the cysts was sieved through a $20 \mu \mathrm{m}$ mesh and washed several times to eliminate PST. The final aliquot collected was used for the quantification of dinoflagellate RCs using sedimentation chambers $(3 \mathrm{ml})$, with an inverted photonic microscope. Densities were expressed as cysts $\mathrm{g}^{-1}$ dry sediment (DS).

\subsubsection{Efficacy of PST extraction method}

The density gradient method could underestimate the density of RCs in a sediment sample (Yamaguchi et al., 1996). In order to evaluate the extraction efficacy (EF) factor, the pellet resulting from the PST extraction (15 replicates) was re-suspended in $50 \mu \mathrm{l}$ diluted PST and then centrifuged five consecutive times. After each PST centrifugation, aliquots were collected and washed for RC quantification, and the remaining pellet was subjected to the successive PST extraction. EF factor was calculated using the following equation (Eq. (3)):

\section{$\mathrm{EF}=\%$ total $\mathrm{RC}$ extracted $/ \% \mathrm{RC}$ of $1 \mathrm{st}$ extraction}

Estimated RC density for all samples was calculated using EF factor, following this equation (Eq. (4)):

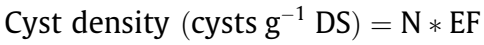

were $\mathrm{N}$ is the RC density/ml observed under inverted microscope after one PST extraction and EF is the extraction efficacy factor.

\subsection{Resting cysts and vegetative cells identification}

RC identification was based on microscopic observation of the morphology of the cysts and of the resulting vegetative cells obtained from excystment experiments. The cysts were isolated with a micropipette onto 96-culture plates (Nunc ${ }^{\mathrm{TM}}$ Delta surface), filled with Enriched Natural Sea Water (ENSW) culture medium (Harrison et al., 1980), with the salinity being adjusted to $34 \mathrm{ppt}$ using autoclaved distilled water. The incubation conditions adopted for the cysts consisted of a water temperature of $20^{\circ} \mathrm{C}$, a light intensity of $100 \mu$ moles photons $\mathrm{m}^{-2} \mathrm{~s}^{-1}$ and a $12 \mathrm{~h}: 12 \mathrm{~h}$ light:dark ratio. When germination occurred, the morphology of A. pseudogonyaulax motile cells and of empty cysts was investigated. Plate tabulation and the arrangements of thecal plates were studied on up to 30 vegetative cells after dissecting the thecae using $5 \%$ sodium hypochlorite solution. Tabular notations were used following Balech (1995) nomenclature. Light micrographs were taken using a Leica DFC 290 camera coupled to a Leica DM2500 microscope. The length and width of the cells was determined at different stages of the exponential phase of growth $(n=30)$.

\subsection{Analyses of nutrients in the sediment-water interface}

Water samples taken at the bottom of the lagoon near the sediment surface were used for nutrient analysis and Alexandrium spp. vegetative cell counts.

About $500 \mathrm{ml}$ of deep water was stored in the freezer for chemical analysis. Nutrients were analyzed using conventional colorimetric methods through an automated channel Technicon autoanalyzer, according to the protocols defined by Tréguer and Le Corre (1975) and the supporting documentation of a UV-visible spectrophotometer "Jenway 6315". Seven independent analyses were performed for each sample. Ammonium analyses were carried out using a spectrophotometric method according to Aminot and Chaussepied (1983).

About $500 \mathrm{ml}$ of deep water were fixed with neutralized formalin for Alexandrium spp. cell quantification and water subsamples having a volume of $25 \mathrm{ml}$ were analyzed using a Leitz inverted microscope (Esselte Leitz GmbH, Germany), following the Utermöhl method (Throndsen, 1995).

\subsection{Statistics}

Several statistical tests were applied in order to investigate the correlations between sediment characteristics, nutrient concentrations and A. pseudogonyaulax RC densities. The Principal Component Analysis (PCA) test was performed in order to investigate correlations between the RC density and the main environmental characteristics (granulometric fractions, biochemical components and water nutrients). Hierarchical Cluster analyses (HCA) was performed in order to cluster the sampling stations on the basis of the environmental characteristics using the Ward aggregation method. The Silhouette Index was applied so as to further test for the homogeneity of clusters. All statistics were performed using the R software (available online at: http://www.r-project.org).

\subsubsection{Spatial autocorrelation of cyst densities}

Results from spatially-adjacent sampling stations are more likely to be similar to each other than results from randomlylocated sampling stations (Legendre, 1993; Legendre and Legendre, 1998). In order to eliminate such bias, we tried to detect the existence of organized spatial structures for RC distribution using a spatial autocorrelation test, the Moran's I index. The neighbor weights were defined in order to highlight the relationships among spatial observations based on a Delaunay triangulation these were calculated using Moran.mc function from spdep R-package. The permutation test for Moran's I statistic was run by using random permutations of the variable to investigate whether the observed Moran's I index values were due to chance or not. A final multivariate autocorrelation was performed, using the function ultispati.rand test from ade4 R-package and MonteCarlo test (Smouse and Peakall, 1999; Chessel et al., 2004), so as to reveal any spatial auto-correlation between all the investigated parameters and so as to justify the use of the Simultaneous Autoregressive Models.

\subsubsection{Simultaneous autoregressive models}

A Simultaneous Autoregressive (SAR) model was developed in order to analyze the predictive power of environmental characteristics for determining resting cyst abundance. However, the presence of spatial autocorrelation in the data is problematic for classical statistical tests such as ordinary least-square regressions, which assume independently-distributed errors. As an alternative, spatial regression models, in particular simultaneous autoregressive (SAR) models, were applied, incorporating the spatial autocorrelation structure among observations. In this analysis, RC density was the dependent variable and water depth, the proportion of different sediment fractions, water content, organic matter content and deep water nutrient concentrations were the independent or explanatory variables. The SAR model was estimated using the spdep package. SAR was carried out using the "correlog" function provided within the R library, spdep'. The statistical difference between the observed Moran's I index and those due to chance (generated in turn using a permutation test) was tested in order 

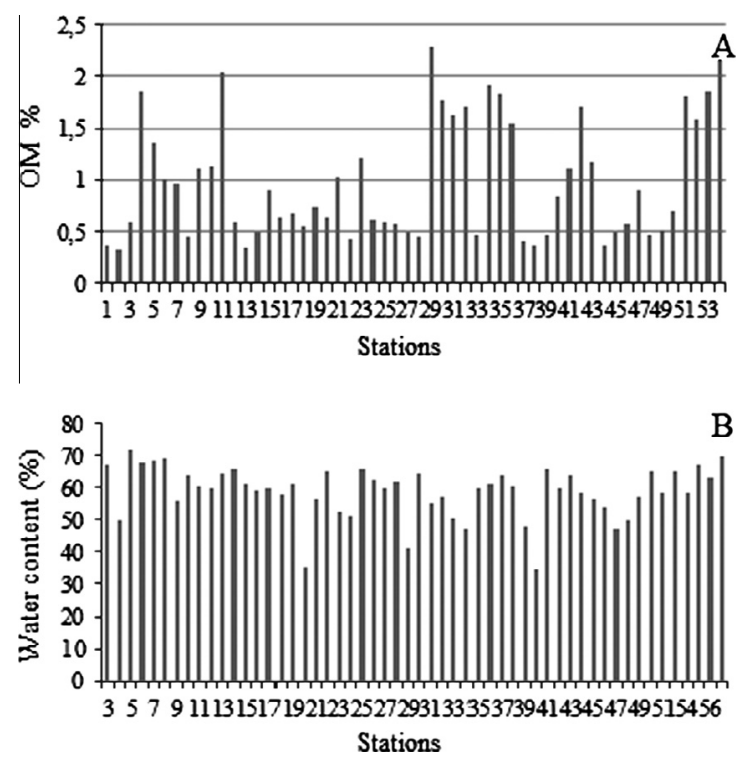

Fig. 3. Water content in\% (A) and organic matter content in\% (B) in Bizerte lagoonsampled stations.

to check for the spatial independence of our model residuals. Finally, for each model, the coefficient of determination, the coefficient for each explanatory variable and its associated $p$-value, and the Akaike's Information Criterion (AIC) were calculated.

\section{Results}

\subsection{Sediment characteristics}

\subsubsection{Water and organic matter (OM) content}

The sediment within the Bizerte lagoon contains a high fraction of water $(58.89 \pm 8.02 \%$ ) (Fig. $3 \mathrm{~A})$. OM content ranged between $0.33 \%$ for station 4 to $2.28 \%$ for station 31 (Fig. 3B). The highest OM values corresponded to the stations located near mussel farms. The Pearson's statistical test analysis revealed a positive correlation $(\alpha=0.05$; $p$-value $=0.002$ ) between water content and RC density, but no significant correlation was found between OM and RC density (Table 1). The organic matter distribution showed a homogeneous pattern for all the sampling stations, with the OM percentage not exceeding $2.28 \%$ of dry sediment.

\subsubsection{Granulometry}

The distribution of fine sediment fraction and coarse sediment fraction revealed two types of sediments: sandy-mud sediments and muddy sediments. The fine fraction $(<63 \mu \mathrm{m})$ dominated sediment samples and was positively correlated with cyst abundance distribution (Table 1). It ranged between $50.48 \%$ and $97.6 \%$ of sediment sample weight and was mainly represented by silt $(60.56 \pm 3.5 \%)$ (Fig. 4). The clay fraction was less abundant $(17.99 \pm 8.46 \%)$. There was a significant correlation $(p<0.1)$ between cyst abundance and silt fraction across Bizerte lagoon (Table 1). RC densities were positively correlated with total silt fraction $(p=0.02)$ and negatively correlated with coarse sand fraction $(p=0.08)$ and fine clay $(p=0.08)$. Moran's I index values showed a significant spatial autocorrelation for all granulometric fractions $(p<0.02)$ (Table 2).

\subsection{Nutrient concentrations and A. pseudogonyaulax densities in deep water layer}

Mean measured nitrogen compound concentrations calculated for the samples stations were $4.5 \pm 3.78 \mu \mathrm{atg} \mathrm{L}^{-1}$ for ammonium,
Table 1

Correlation between Alexandrium pseudogonyaulax resting cysts densities and the main environmental factors (depth, nutrients and sediment characteristics).

\begin{tabular}{lcl}
\hline Environmental factors & Correlation & P-value \\
\hline $\mathrm{NH}_{4}^{+}$ & -0.06 & 0.69 \\
$\mathrm{NO}_{2}^{-}$ & 0.15 & 0.28 \\
$\mathrm{NO}_{3}^{+}$ & -0.16 & 0.24 \\
$\mathrm{PO}_{4}^{3-}$ & -0.11 & 0.44 \\
Water content & $\mathbf{0 . 4 1}$ & $\mathbf{0 . 0 0 2}$ \\
MO & -0.18 & 0.20 \\
Fine fraction $(0-63 \mu \mathrm{m})$ & 0.17 & 0.21 \\
Coarse fraction $\left(63 \mu \mathrm{m}^{-1} \mathrm{~mm}\right)$ & -0.1753 & 0.21 \\
Fine clay $(0-2 \mu \mathrm{m})$ & -0.24 & 0.08 \\
Coarse clay $(2-4 \mu \mathrm{m})$ & 0.17 & 0.22 \\
Total clay $(0-4 \mu \mathrm{m})$ & -0.21 & 0.13 \\
Fine silt $(4-30 \mu \mathrm{m})$ & 0.26 & 0.06 \\
Coarse silt $(30-63 \mu \mathrm{m})$ & 0.19 & 0.16 \\
Total silt $\left(4-63 \mu \mathrm{m}^{3}\right)$ & $\mathbf{0 . 3 2}$ & $\mathbf{0 . 0 2}$ \\
Fine sand $(63-200 \mu \mathrm{m})$ & 0.02 & 0.88 \\
Coarse sand $\left(200 \mu \mathrm{m}^{-1} \mathrm{~mm}\right)$ & -0.24 & 0.08 \\
Total sand $\left(63 \mu \mathrm{m}^{-1} \mathrm{~mm}\right)$ & 0.17 & 0.21 \\
Depth & 0.14 & 0.31 \\
\hline
\end{tabular}

Positive correlation are shown in bold.

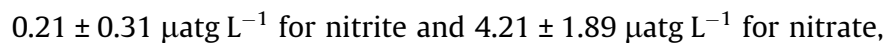
whereas the mean phosphate concentration was that of $0.23 \pm 0.28 \mu \operatorname{atg~L^{-1}}$. The correlations between overlying water column nutrient and sediment characteristics were estimated. Nitrite was negatively correlated with the fine sediment fraction and positively correlated with the coarse fraction (Supplementary Table 1). The determination of the densities of $A$. pseudogonyaulax in the deep water revealed a mean cell concentration of $15 \pm 88$ cells $\mathrm{L}^{-1}$ calculated over all of the sampled stations. The highest density of A. pseudogonyaulax was registered at station 5 with 640 cells $\mathrm{L}^{-1}$.

\subsection{A. pseudogonyaulax vegetative cells and resting cyst morphology}

A. Pseudogonyaulax resting cysts were spherical or oval and could be classified in two types, depending on their wall organization. The first type has a paratabulate wall (Fig. 5A-C), corresponding to the description by Montresor (1995); when suture ridges in surface cysts are strongly marked, they can be also be observed before excystment. The second type has a smooth common wall (Fig. 5D). RC diameter was highly variable, ranging between 40 and $72 \mu \mathrm{m}(n=30)$. Cyst content was characterized by dark brownish yellow vesicles. Both cyst types were observed either in surface sediment $(0-3 \mathrm{~cm})$ or in deeper parts of the sediment $(4-6 \mathrm{~cm})$. Successful germination of cysts occurred in diluted ENSW medium, at standard incubation conditions $\left(100 \mu \mathrm{mol}\right.$ photons $\mathrm{m}^{-2} \mathrm{~s}^{-1}$, $20^{\circ} \mathrm{C}$ and salinity 34). Excystment success $(n=78)$ allowed us to identify the isolated cysts as those of $A$. pseudogonyaulax species. Vegetative cells have a typical flattened shape, with an epitheca slightly smaller than the hypotheca (Fig. 5E). Dissection of thecal plates in vegetative cells showed a lack of contact between the apical pore plate (Po) and the first apical plate (1'), with the presence of a ventral pore in the first plate (1') (Fig. 5F). Vegetative cells have numerous chloroplasts and a typical U-shaped nucleus (Fig. 5G, H).

\subsection{Accuracy of the resting cysts quantification method}

Five extractions were necessary to collect all RCs in one gram of sediment. Most of the RCs were recovered through the first extraction (mean: $64.86 \pm 6.6$ ) (Table 3 ) with values for extraction success ranging between $55.77 \%$ and $77.3 \%$. Few RCs were recovered through the last extraction (mean: $0.99 \pm 1.1 \%$ ). The number of recovered RCs decreased progressively with successive extractions and the cumulative percentage of recovered RCs reached nearly 


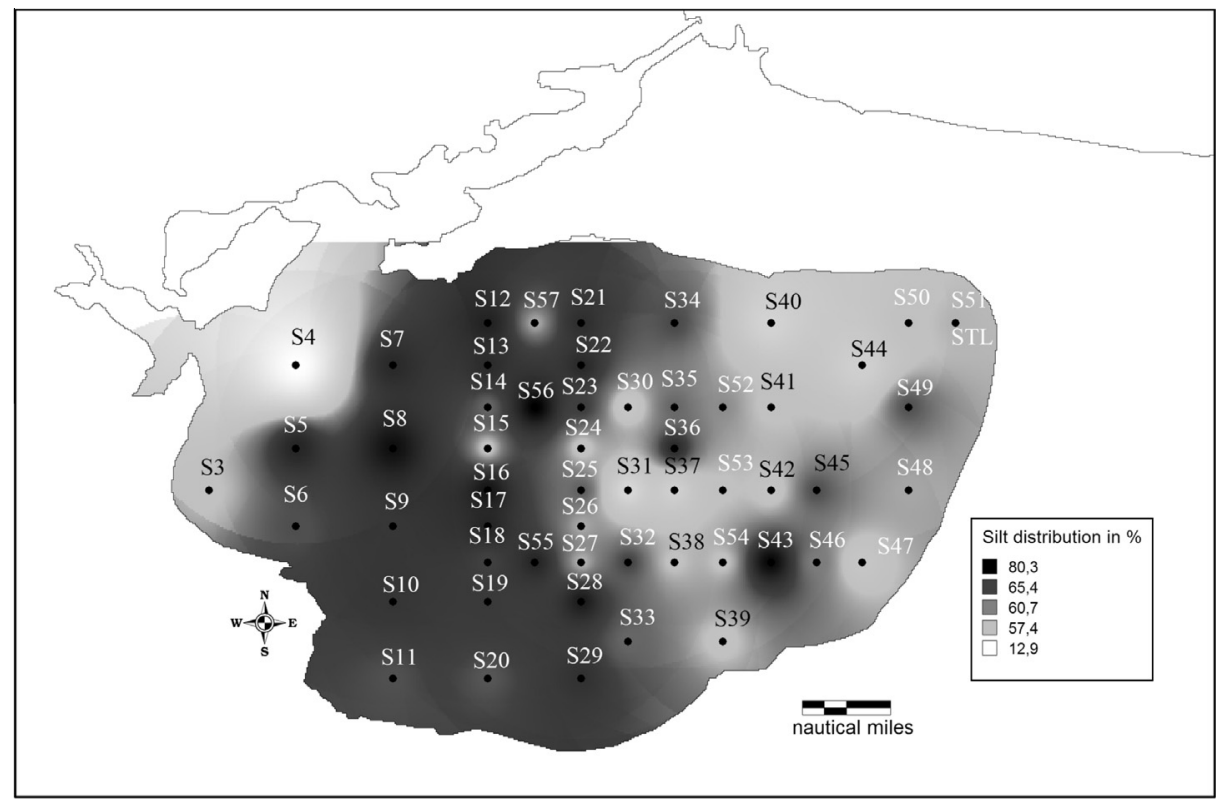

Fig. 4. Silty fraction in Bizerte lagoon sediment.

Table 2

Permutation test for Moran's I.

\begin{tabular}{lcc}
\hline & Observed statistics & $P$-value \\
\hline Alexandrium pseudonyaulax & 0.287 & 0.001 \\
$\mathrm{NH}_{4}^{+}$ & 0.404 & 0.001 \\
$\mathrm{NO}_{2}^{-}$ & 0.187 & 0.011 \\
$\mathrm{NO}_{3}^{+}$ & -0.046 & 0.608 \\
$\mathrm{PO}_{4}^{3-}$ & -0.027 & 0.515 \\
Water content & 0.207 & 0.009 \\
Organic matter & 0.094 & 0.063 \\
Fine fraction $(0-63 \mu \mathrm{m})$ & 0.290 & 0.001 \\
Coarse fraction $\left(63 \mu \mathrm{m}^{-1} \mathrm{~mm}\right)$ & 0.290 & 0.002 \\
Fine clay $(0-2 \mu \mathrm{m})$ & 0.310 & 0.001 \\
Coarse clay $(2-4 \mu \mathrm{m})$ & 0.266 & 0.001 \\
Total clay $(0-4 \mu \mathrm{m})$ & 0.309 & 0.001 \\
Fine silt $(4-30 \mu \mathrm{m})$ & 0.292 & 0.001 \\
Coarse silt $(30-63 \mu \mathrm{m})$ & 0.237 & 0.001 \\
Total silt $(4-63 \mu \mathrm{m})$ & 0.221 & 0.002 \\
Fine sand $(63-200 \mu \mathrm{m})$ & 0.334 & 0.001 \\
Coarse sand $\left(200 \mu \mathrm{m}{ }^{-1} \mathrm{~mm}\right)$ & 0.191 & 0.005 \\
Total sand & 0.289 & 0.001 \\
\hline
\end{tabular}

$96 \%$ at the 3rd extraction (Fig. 6). As the extraction of cysts from sediment is tedious and time-consuming, and in view of the fact that the first extraction under-estimates RC densities by an extraction efficacy factor of 1.56 , we adjusted all the RC densities obtained from the first extraction by applying this correction factor.

\subsection{Mapping of A. pseudogonyaulax in Bizerte lagoon and statistical analyses}

A. pseudogonyaulax cysts accumulated in surface sediment of the whole lagoon showed different densities in function of the geographical location of the investigated station (Fig. 7). The highest

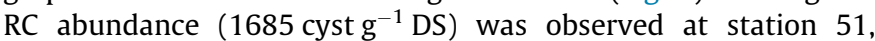

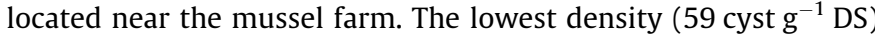
was observed at station 27 located within the central portion of the lagoon. RC distribution extends over the entire lagoon and two areas with high cyst densities were detected. The first area (sampling stations 5, 8, 10 and 55) was located in the southwestern part of the lagoon, where RC densities reached
1551 cyst g $^{-1}$ DS at station 10 . The second area was located at the opposite extremity, within the north-eastern part of the lagoon (stations 41, 44, 50 and 51), where RC density reached

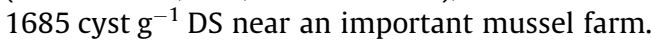

PCA was performed to investigate any correlation between the distribution of RC densities and environmental variables. The length of the arrows (environmental variables), orientation and angle with the axes indicate the relative importance of such variables and approximate correlations between the two axes. PCA (Fig. 8) axes 1 and 2 accounted for $57.1 \%$ of the correlation between A. pseudogonyaulax RC densities and environmental factors. PC1, explaining $44.6 \%$ of correlation, was mainly represented by the total sediment fine fraction $(<63 \mu \mathrm{m})$ and silt fractions. The PCA revealed a positive correlation between RC densities and the sediment silt fraction.

Hierarchical Cluster analyses were obtained using Euclidean distance and the Aggregation Ward method. Three clusters emerged, on the basis of sediment granulometry and overlying water column nutrient concentrations (Fig. 9). The Silhouette Index (Fig. 10) gave a good homogeneity for cluster 1 and 2. Most of the sampling stations having high RC densities were close to PC1, represented by the silt fraction.

Spatial autocorrelation analyses revealed that the resting cyst distribution in Bizerte lagoon was highly spatially correlated ( $p$ value $=0.001)$ (Table 1$)$. Using 1000 randomizations under the null hypothesis (i.e. no spatial influence on the distribution of cyst densities), a Moran I index value of $0.072(p$-value $=0.003)$ indicated that spatially close sampling stations had more similar cyst densities than was randomly expected.

Classic linear regression showed a relationship between $A$. pseudogonyaulax RC density and the sediment fraction ( $p$-value $=0.009$ ) but this relationship was not linear $\left(R^{2}=0.46\right)$. A Boxcox transformation clearly gave us an improvement for the $R^{2}$ values obtained. Moran I index values revealed a strong degree of co-linearity between different environmental parameters - as a result, the application of Simultaneous Autoregressive Models (SAR) was necessary in order to remove this spatial autocorrelation in the residuals, and a backward stepwise method was performed to retain the most significant variables in explaining observed A. pseudogonyaulax densities. The final SAR model gave two explanatory environmental variables: $\mathrm{H}_{2} \mathrm{O}$ content and $\mathrm{NO}_{3}^{-}$, 


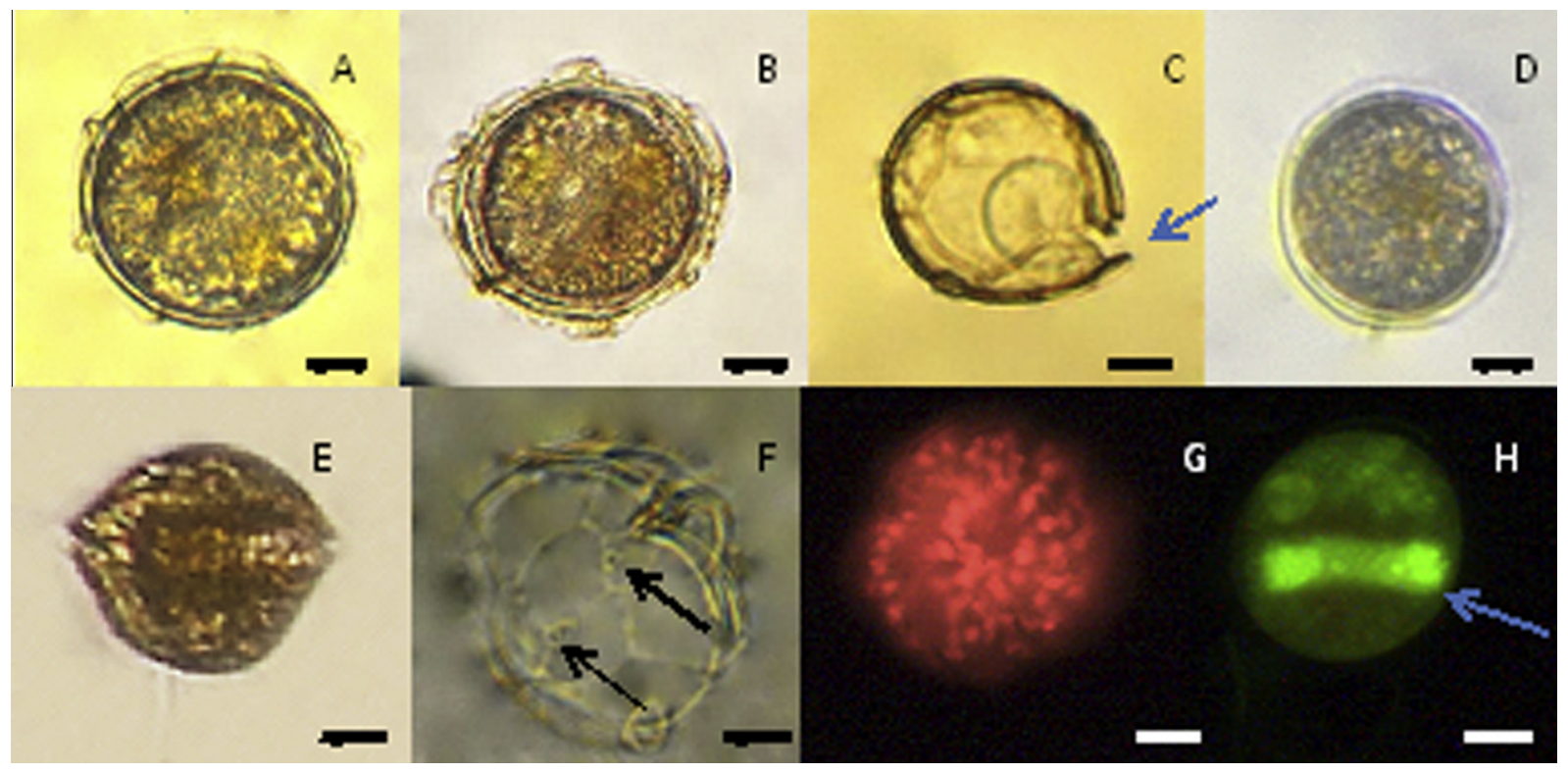

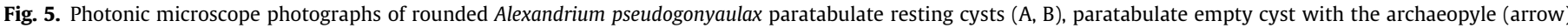

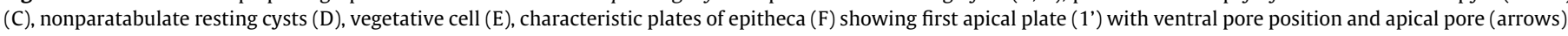
numerous chloroplast organelles $(\mathrm{G})$ and $U$-Shaped nucleus stained with DAPI $(\mathrm{H})$. Scale bar $(10 \mu \mathrm{m})$.

Table 3

Descriptive data of extraction accuracy of Alexandrium pseudogonaulax cyst densities (cysts $\mathrm{g}^{-1} \mathrm{DS}$ ).

\begin{tabular}{lllll}
\hline Extraction No. & Min (\%) & Max (\%) & Average (\%) & SD (\%) \\
\hline 1 & 55.77 & 77.30 & 64.86 & 6.66 \\
2 & 12.27 & 32.28 & 22.77 & 6.29 \\
3 & 2.68 & 14.19 & 8.43 & 4.35 \\
4 & 0.82 & 7.32 & 3.15 & 2.29 \\
5 & 0 & 4.29 & 0.99 & 1.17 \\
\hline
\end{tabular}

which were significantly related to resting cyst density $(p=0.001)$. A. pseudogonyaulax RC density is thus best expressed through the following equation (Eq. (5)):

$\left[(\text { A.pseudo })^{0.15}-1\right] / 0.15=0.300646$ Water content

-1.207665 fine clay +0.351146 fine silt.

\section{Discussion}

A detailed spatial distribution of $A$. pseudogonyaulax resting cysts in superficial benthic sediments $(0-3 \mathrm{~cm})$ is reported for the first time from a Mediterranean lagoon. Cyst densities exhibited high values across the entire lagoon. Whereas the cyst densities were high, no bloom of this species was observed. Turki (2004) showed that $A$. pseudogonyaulax cell densities reached 8750 cells $\mathrm{L}^{-1}$ in the Bizerte lagoon, whilst in our study, the maximum vegetative cell density encountered during the survey was that of 640 cells $\mathrm{L}^{-1}$. The mean resting cyst density recorded in this study was 639 cysts $\mathrm{g}^{-1}$ DS and this appears to be high when compared to Alexandrium cyst distribution in other marine areas (Genovesi et al., 2013). With comparable cyst densities as Bizerte Lagoon, many other coastal systems showed considerable blooms of Alexandrium spp., characterized by cell densities $>10^{6}$ cells $\mathrm{L}^{-1}$ (Yamaguchi et al., 1996; Horner et al., 2011; Gracia et al., 2013; Genovesi et al., 2013). Our results revealed the presence of two A. pseudogonyaulax cysts seedbeds in Bizerte lagoon. The first one is located in the southwestern part of the lagoon, with concentrations reaching 1551 cysts $\mathrm{g}^{-1} \mathrm{DS}$, and the second one is located in the

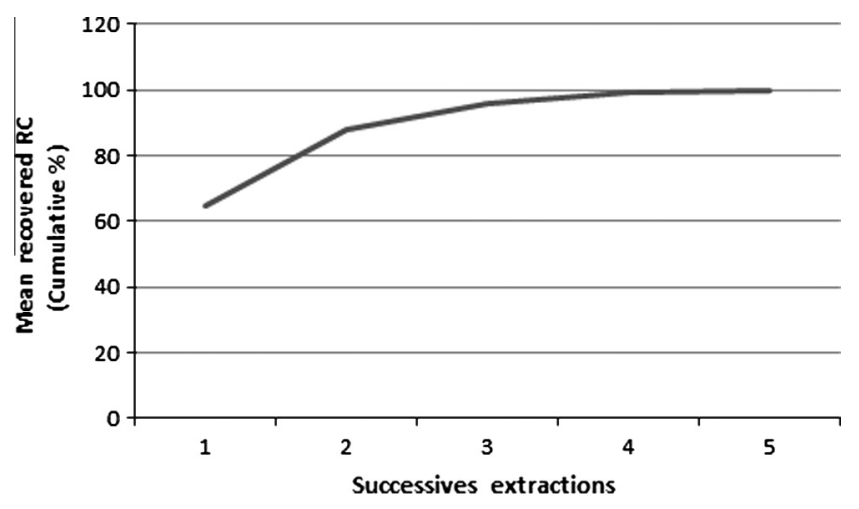

Fig. 6. Evolution of cumulative percentage of recovered resting cysts at the end of the 5 successive extractions PST density gradient technique ( $n=15$ replicates).

northeastern part of the lagoon with cell densities reaching a maximum value of 1685 cyst $\mathrm{g}^{-1} \mathrm{DS}$. The high A. pseudogonyaulax cyst densities encountered in recently-deposited benthic sediment of Bizerte lagoon suggests that this lagoon was previously subjected to blooms of this dinoflagellate, with the vegetative cells producing resistant cysts, which in turn settled in response to the prevailing hydrodynamic features within the lagoon. One can speculate that these blooms were highly localized and that the implemented HAB phytoplankton species monitoring program in Bizerte lagoon failed to detect these events. This is in agreement with Genovesi et al. (2013), who showed in their study on the Thau lagoon that Alexandrium catenella/tamarense cyst densities varied widely among sampled stations, with the highest density (440 cysts $\mathrm{g}^{-1}$ DS) being recorded in a shallow cove named Crique-de-l'Angle, which is the only area where dense blooms of Alexandrium had been recorded previously and during the actual study. Also, excystment experiments performed on A. pseudogonyaulax RCs extracted from Bizerte Lagoon (unpublished data) revealed a low rate of germination, and when cells did germinate, only a few of them were able to establish a sibling culture. These considerations could explain the failure of $A$. pseudogonyaulax to bloom over large areas of Bizerte lagoon. It has been also suggested that that the mismatch between 


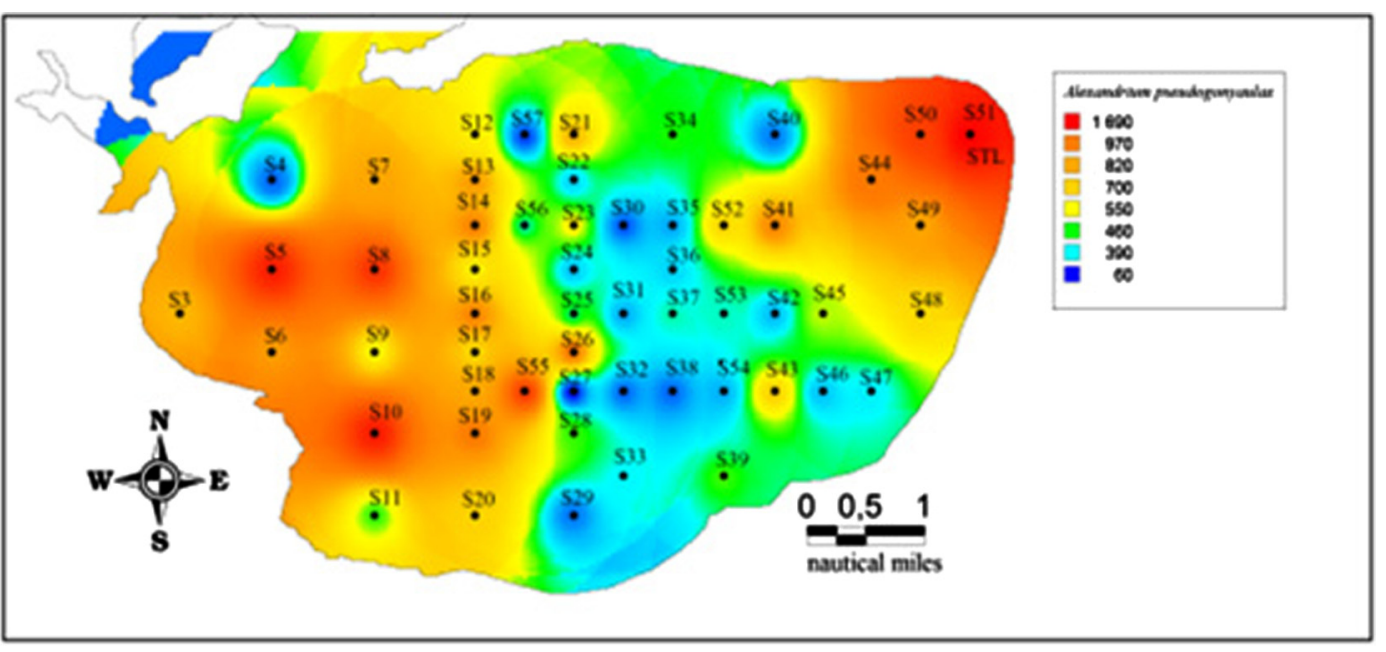

Fig. 7. Spatial distribution of Alexandrium pseudogonyaulax resting cysts in Bizerte lagoon ( $\left.\mathrm{RC}^{-1} \mathrm{DS}\right)$.

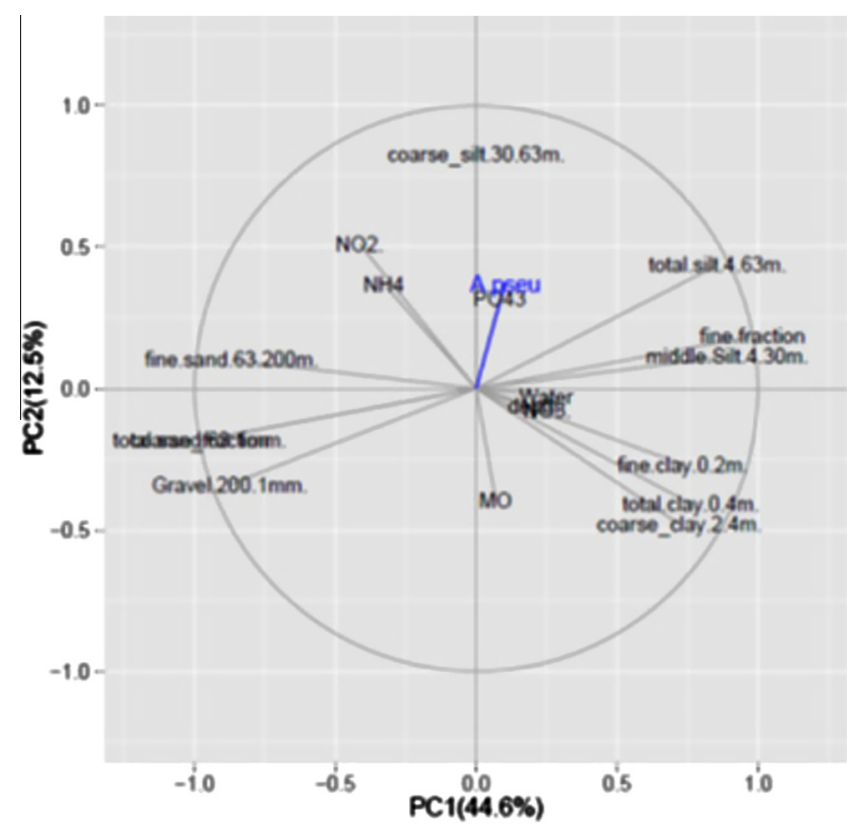

Fig. 8. Principal Component Analyses circle highlighting correlations. Alexandrium pseudogonyaulax cyst density is considered as a supplementary variable.

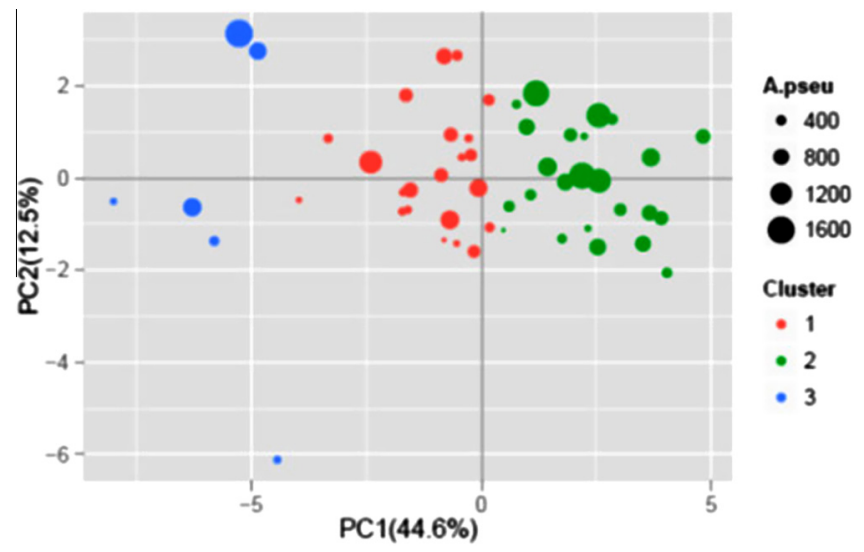

Fig. 9. Principal Component Analyses performed on the first two axes based on HAC clustering.

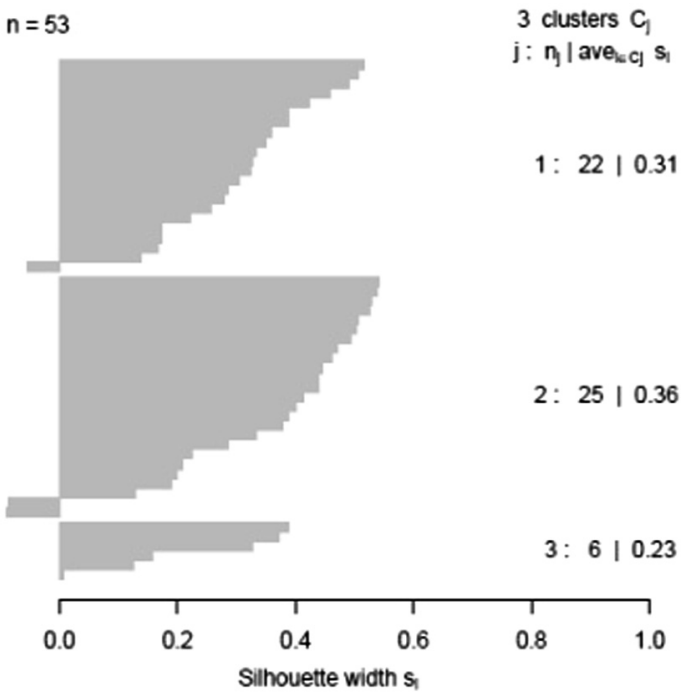

Average silhouette width : 0.32

Fig. 10. Silouhette index highlighting homogeneity of three groups of cysts.

high cyst densities and few vegetative cells encountered may reflect variable degrees of mixing of young surface cysts with older, less viable cysts from deeper sediment layers (Gracia et al., 2013).

Previous studies (Harzallah, 2003; Bejaoui and Harzallah, 2005; Bejaoui et al., 2008; Bejaoui, 2009) indicated that Bizerte lagoon is characterized by low degrees of hydrodynamic energy at the bottom and mid-layers of the water column. Energy transmitted to the water layer contiguous to the sediment surface might not be high enough for resting cysts to be re-suspended out of the sediment in these parts of the lagoon. However, in other areas of the lagoon, peripheral bottom currents and waves could play a role in promoting the mixing of sediments and in creating a permanent mobilization of the superficial deposits and re-suspension may occur to a greater degree in these areas.

The distribution and settlement of dinoflagellate resting cysts are influenced mainly by several environmental factors such as sediment particle size, sedimentation rate and hydrodynamic features (Genovesi et al., 2013 and references therein), as well as by biological factors (White and Lewis, 1982). Dinocysts show different responses to nutrient enrichment and pollutants (Dale, 2001, 2009; Matsuoka, 2001). It has been shown that nutrient 
A

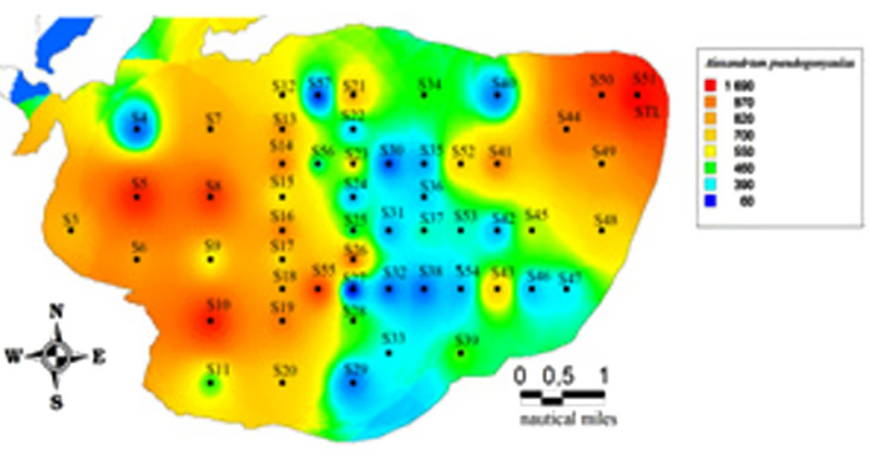

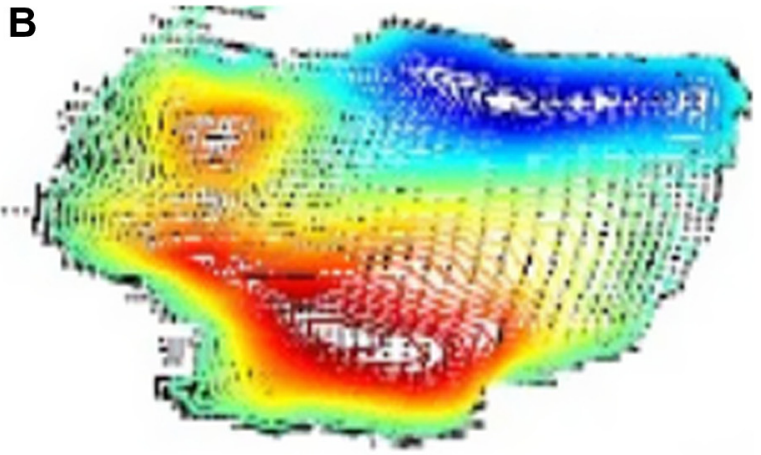

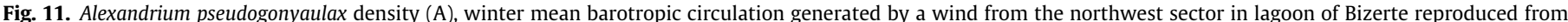
Bejaoui (2009) (B).

enrichment could significantly increase the abundance of dinocysts and industrial pollution could decrease cyst abundance or change the heterotrophic-phototrophic cysts ratio (Matsuoka, 2001; Liu et al., 2012).

Weak exchanges of sediment between the lagoon and the Mediterranean Sea through a geological bottleneck have favored the deposition of silt on the lagunar seabed, which has the shape of an ellipsoidal depression. A. pseudogonyaulax RC densities were positively correlated ( $p$-value $=0.02$ ) with the sediment total silt content and strongly negatively correlated with coarse sand ( $p$-value $=0.08)$. The positive correlation between RC densities and silt fraction suggest that sediment containing a certain proportion of silt was more likely to contain relatively high cyst densities. This high correlation confirmed that RCs behaves as passive sediment particles, consequently being subject to re-suspension and they can be transported by water currents, thus favoring their dispersal to new areas. Our results are consistent with those of Yamaguchi et al. (1996), Gayoso (2001), Joyce et al. (2005), White and Lewis (1982), Anderson et al. (2005), Anglès et al. (2010) and Horner et al. (2011), which showed that major resting cyst accumulation occurred in sediments containing a high proportion of fine fraction $(<63 \mu \mathrm{m})$.

The prevailing hydrodynamic features of Bizerte lagoon are mainly the result of dominant wind patterns. Surface water currents are important, but, in the central and the deepest areas of the lagoon, the wind influence and surface currents weaken and the direction of water flow is reversed towards the northwest direction through the central portions of the lagoon (Harzallah, 2003; Bejaoui et al., 2008; Bejaoui, 2009). The water currents map for the lagoon highlights a two wind-current gyratory flow sweeping the entire western part of lagoon, which could promote re-suspension and spread of RCs and could explain the homogeneous pattern of cyst distribution observed in the western part of lagoon (Fig. 11). In addition, the southeastern part of the lagoon is subject to sediment inputs through the erosion of soil on contiguous cultivated land which is brought by rivers and which can cover sedimented cysts on the lagoon seabed, with the cysts being relocated to the sediment superficial surface by peripheral winddriven surface currents which force re-suspension. This phenomenon tends to stem the decrease in RC abundance in this part of lagoon, where cysts densities are lower than those observed on the western side but are also higher than those recorded in some central stations of the same lagoon.

\section{Conclusion}

This study presents the first cyst map for a Mediterranean coastal ecosystem for A. pseudogonyaulax, which is reported as potentially toxic dinoflagellate producing Goniodomin A. RC densities were high and spatially autocorrelated across the lagoon. Statistical analyses showed positive correlations between sediment silt fraction and water content values with RC densities. This might suggest that bottom sediment rich in silt with high water content may represent the optimum environmental conditions for the settlement of resting cysts. Hydrodynamic factors in Bizerte lagoon could influence the spatial autocorrelation between cysts distribution and environmental factors. The presence of centrifugal forces favors the accumulation of RCs in some areas of the lagoon. A. pseudogonyaulax cysts present in large densities in certain sampling stations could potentially inoculate the water column and be responsible for dense blooms of the species. Since this species is a renowned fish-killer, capable of producing Goniodomin A, the survey reported in this study should be extended to a larger number of sampling stations on the basis of the known spatial distribution of resting cysts. The chemical structure of the toxins released by the vegetative cells of $A$. pseudogonyaulax should also be elucidated.

\section{Acknowledgements}

This work benefitted from financial supports from the JEAI ECOBIZ (Jeune Equipe Associée, Ecologie de la lagune de Bizerte) program funded by IRD (Institut Français pour la Recherche et le Développement), IRD also funded 2 months stay of Dr. Mohamed Laabir in Tunis (INAT). Thanks to TOTAL Foundation for funding LAGUNOTOX project which supported financially the stay of Mrs Triki-Zmerli in Montpellier.

\section{Appendix A. Supplementary material}

Supplementary data associated with this article can be found, in the online version, at http://dx.doi.org/10.1016/j.marpolbul.2014. 05.014 .

\section{References}

Aminot, A., Chaussepied, M., 1983. Manuel des analyses chimiques en milieu marin. Centre National pour l'Exploitation des Océans, pp. 395.

Anderson, D.M., Wall, D., 1978. Potential importance of benthic cysts of Gonyaulax tamarensis and G. excavata in initiating toxic dinoflagellate blooms. J. Phycol. 14 (2), 224-234

Anderson, D.M., Stock, C.A., Keafer, B.A., Nelson, A.B., Thompson, B., McGillicuddy Jr., D.J., Keller, M., Matrai, P.A., Martin, J., 2005. Alexandrium fundyense cyst dynamics in the Gulf of Maine. Deep-Sea Res. II 52, 2522-2542.

Anglès, S., Jordi, A., Garcés, E., Basterretxea, G., Palanques, A., 2010. Alexandrium minutum resting cyst distribution dynamics in a confined site. Deep-Sea Res. II 57, 210-221.

Balech, E., 1995. The Genus Alexandrium Halim (Dinoflagellata). Sherkin Island Marine Station, Ireland, pp. 151 
Bejaoui, B., 2009. Développement d'un modèle Tridimentionnel couplé Dynamiqueécologie: Application à la lagune de Bizerte. Rapport de thèse spécialité en génie hydraulique. ENIT. Département hydraulique, Tunisie, pp. 210.

Bejaoui, B., Harzallah, A., 2005. Modèle hydrodynamique de la lagune de Bizerte avec forçage saisonnier. Atelier de Modélisation des Écosystèmes Marins, organisé par l'INSTM, Tunis, 27-28 Septembre 2005.

Bejaoui, B., Harzallah, A., Moussa, M., Chapelle, A., Solidoro, C., 2008. Analysis of hydrobiological pattern in the Bizerte lagoon (Tunisia). Estuar Coast Shelf S. 80, 121-129.

Belmonte, G., Miglietta, A., Rubino, F., Boero, F., 1997. Morphological convergence of resting stages of planktonic organisms: a review. Hydrobiologia 355, 159-165.

Ben Naila, I. Hamza, A. Gdoura, R., Diogéne, J., De la Iglesia, P. 2012. Prevalence and persistence of gymnodimines in clams from the Gulf of Gabès (Tunisia) studied by mouse bioassay and LC-MS/MS. Harmful Algae. 18, 56-64.

Biecheler, B., 1952. Recherches sur les Péridinens. Bull. Biol. France Belgique Suppl. $36,1-149$.

Blossom, H.E., Daugbjerg, N., Hansen, P.J., 2012. Toxic mucus traps: a novel mechanism that mediates prey uptake in the mixotrophic dinoflagellate Alexandrium pseudogonyaulax. Harmful Algae. 17, 40-53.

Brahim, M., Bejaoui, B., Atoui, A., 2008. Etude de l'hydrodynamique sédimentaire de la lagune de Bizerte. Bull. Inst. Natn. Scien. Tech Mer de Salammbô. 35, 160.

Bravo, I., Garcés, E., Diogène, J., Fraga, S., Sampedro, N., Figueroa, R.I., 2006. Resting cysts of the toxigenic dinoflagellate genus Alexandrium in recent sediments from the Western Mediterranean coast, including the first description of cysts of A. kutnerae and A. peruvianum. Eur. J. Phycol. 41 (3), 293-302.

Chessel, D., Dufour, A.B., Thioulouse, J., 2004. The ade4 package-I-one-table methods. R News. 4, 5-10.

Dale, B., 1983. Dinoflagellate resting cysts: "benthic plankton”. In: Fryxell, G.A. (Ed.) Survival Strategies of the Algae. Cambridge University Press, Cambridge, pp. 69136.

Dale, B., 2001. Marine dinoflagellate cysts as indicators of eutrophication and industrial pollution: a discussion. Sci. Total Environ. 264, 235-240.

Dale, B., 2009. Eutrophication signals in the sedimentary record of dinoflagellate cysts in coastal waters. J. Sea Res. 61, 103-113.

Daly Yahia-Kefi, O., Nézan, E., Daly Yahia, M.N., 2001. Sur la présence du genre Alexandrium halim(Dinoflagellés) dans la baie de Tunis (Tunisie). Oceanol. Acta $24,17-25$.

Faust, M.A., Gulledge, R.A., 2002. Identifying harmful marine dinoflagellates Smithsonian Institution. Department of Systematic Biology - Botany. United States National Herbarium 42, 1-144.

Gayoso, A.M., 2001. Observation on Alexandrium tamarense (Lebour) Balech and other dinoflagellate population in Golfo Nuevo, Patagonia (Argentina). J. Plankton Res. 23, 463-468.

Genovesi, B., Mouillot, D., Laugier, T., Fiandrino, A., Laabir, M., Vaquer, A., Grzebyk, D., 2013. Influences of sedimentation and hydrodynamics on the spatia distribution of Alexandrium catenella/tamarense resting cysts in a shellfish farming lagoon impacted by toxic blooms. Harmful Algae. 25, 15-25.

Genovesi-Giunti, B., Laabir, M., Vaquer, A., 2006. The benthic resting cyst: a key actor in harmful dinoflagellate blooms - a review. Vie Milieu. 56, 327-337.

Gracia, S., Roy, S., Starr, M., 2013. Spatial distribution and viability of Alexandrium tamarense resting cysts in surface sediments from the St. Lawrence Estuary, Eastern Canada. Estuar. Coast. Shelf S. 121-122, 20-32.

Harrison, P.J., Waters, R., Taylor, F.J.R., 1980. A broad spectrum artificial sea water medium for coastal and open ocean phytoplankton. J. Phycol. 16, 28-35.

Harzallah A., 2003. Transport des polluants dans la lagune de Bizerte simulé par un modèle de circulation de l'eau. Bull. Inst. Nati. Des Sci. Et Tech. de la Mer de Salammbô. 30, 115-133.
Horner, R.A., Greengrove, C.L., Davies-Vollum, K.S., Gawel, J.E., Postel, J.R., Cox, A.M., 2011. Spatial distribution of benthic cysts of Alexandrium catenella in surface sediments of Puget Sound, Washington. USA. Harmful Algae. 11, 96-105.

Joyce, L.B., Pitcher, G.C., Randt, A.d., Monteiro, P.M.S., 2005. Dinoflagellate cysts from surface sediments of Saldanha Bay South Africa: an indication of the potential risk of harmful algal blooms. Harmful Algae. 4, 309-318.

Klein, G., Martin, J.L., Kaczmarska, I., 2010. Biological synopsis of phytoplankton new to the Bay of Fundy. Can. Manuscr. Rep. Fish. Aquat. Sci. 2919, 37.

Legendre, P., 1993. Spatial autocorrelation: trouble or new paradigm? Ecology 74 1659-1673.

Legendre, P., Legendre, L., 1998. Numerical Ecology, second ed. Elsevier, Amsterdam.

Liu, D., Shi, Y., Di, B., Sun, Q., Wang, Y., Dong, Z., Shao, H., 2012. The impact of different pollution sources on modern dinoflagellate cysts in Sishili Bay, Yellow Sea. China. Mar. Micropaleontol. 84-85, 1-13.

Matsuoka, K., 2001. Further evidence for a marine dinoflagellate cyst as an indicator of eutrophication in Yokohama Port, Tokyo Bay, Japan. Comments on a discussion by B. Dale. Sci. Total Environ. 264, 221-233.

Montresor, M., 1995. The life history of Alexandrium pseudogonyaulax (Gonyaulacales, Dinophyceae). Phycologia 34, 444-448.

Murakami, M., Makabe, K., Yamaguchi, S., Konosu, S., Walchi, R., 1988. Goniodomin A, a novel polyether macrolide from the dinoflagellate Goniodoma pseudogoniaulax. Tetrahedron Lett. 29, 1149-1152.

Satta, C., Anglès, S., Garcés, E., Luglie, A. Padedda, B., Sechi, N., 2010. Dinoflagellate cysts in recent sediments from two semi-enclosed areas of the Western Mediterranean Sea subject to high human impact. Deep-Sea Res. II 57 (3-4), 256-267.

Smouse, P.E., Peakall, R., 1999. Spatial autocorrelation analysis of individual multiallele and multilocus genetic structure. Heredity 82, 561p.

Steidinger, K., Garcès, E. 2006. Life cycles of Harmful algae: an overview, In: Graneli, E., Turner, J.T. (Eds.), Ecology of Harmful Algae, Springer Verlag, pp. 37-49.

Throndsen, J. 1995. Estimating cell numbers, In: Hallegraeff, G.M., Anderson, D.M., Cembella, A.D. (Eds.), Manual on harmful marine microalgae. IOC Manuals and Guides 33. UNESCO, pp. 63-80.

Throndsen, J., Hasle, G.R., Tangen, K. 2007. Phytoplankton of Norwegian coastal waters. Almater For lag AS, Oslo. pp. 343.

Tréguer, P., Le Corre, P., 1975. Manuel d'analyse des sels nutritifs dans l'eau de mer (utilisation de l'autoanalyseur II Technicon). Université de Bretagne Occidentale, Laboratoire d'Océanographie chimique, pp. 110.

Turki, S., 2004. Suivi des microalgues potentiellement toxiques dans les zones de production des mollusques bivalves et d'exploitation des oursins du nord de la Tunisie. Bull. Inst. Natn. Scien. Tech. Mer de Salammbô. 31, 83-96.

Turki, S., Balti, N., Ben Jannet, H., 2007. First bloom of dinoflagellate Alexandrium catenella in Bizerte Lagoon (northern Tunisia). Harmful Algae News. 35, 7-9.

White, A.W., Lewis, C.M., 1982. Resting cysts of the toxic, red tide dinoflagellate Gonyaulax excavata in Bay of Fundy sediments. Can. J. Fish. Aquat. Sci. 39, 11851194.

Yamaguchi, M., Itakura, S., Nagasaki, K., Imai, I., 1996. Distribution and abundance of resting cysts of the toxic dinoflagellates Alexandrium tamarense and Alexandrium catenella in sediments of the eastern Seto Inland Sea, Japan. In: Yasumoto, T., Oshima, Y., Fukuyo, Y. (Eds.), Intergovernmental Oceanographic Commission of UNESCO. Laboratory of Bioorganic Chemistry, Tohoku University, Japan, pp. 177-180. 